\title{
A80G polymorphism of reduced folate carrier 1 (RFC1) and C776G polymorphism of transcobalamin 2 (TC2) genes in Down's syndrome etiology
}

\author{
Genetics and Molecular Biology Research Unit, Department of Molecular \\ Biology, Faculdade de Medicina de São José do Rio Preto (Famerp), São José \\ do Rio Preto, São Paulo, Brazil
}

\begin{abstract}
INTRLDUCTION
Down's syndrome (DS) or trisomy 21 is a genetic disease associated with abnormal chromosomal segregation. ${ }^{1}$ Free trisomy 21 is found in $95 \%$ of DS cases and is due to chromosome 21 nondisjunction, which in most cases occurred during maternal meiosis. ${ }^{2}$

The risk factors for meiotic nondisjunction are not very clear, except for advanced maternal age. ${ }^{3,4}$ Folic acid has an important role in the process of genetic material distribution during cell division, because of its importance to cellular methylation reactions. ${ }^{5}$ The folate metabolism is responsible for synthesizing S-adenosylmethionine (SAM), the main donor of methyl groups for cellular methylation reactions. ${ }^{6}$ It has been shown that DNA methylation is important for maintaining centromeric chromatin stability and plays an important role in chromosomal segregation. ${ }^{7,8}$
\end{abstract}

Polymorphisms of genes that encode enzymes involved in folate metabolism have been associated with the etiology of DS. ${ }^{9-12} \mathrm{~A}$ polymorphism of the reduced folate carrier 1 ( $R F C 1$ ) gene consisting of an adenine-to-guanine substitution at position 80 (A80G) has been associated with altered concentrations of products derived from the folate metabolic pathway. ${ }^{13,14}$ This has been indicated as a maternal risk factor for DS, in combination with other polymorphisms involved in this metabolism. ${ }^{911}$ The RFC1 gene encodes the reduced folate carrier 1 protein, which plays a role in folic acid absorption, thereby transporting 5-methyltetrahydrofolate, the metabolically active form of folate, into a variety of cells. ${ }^{15}$

Polymorphisms of genes encoding cobalamin-transporting proteins such as transcobalamin 2 (TC2) may interfere with the availability of this vitamin in the organism. ${ }^{16,17} \mathrm{Co}-$ balamin (vitamin $\mathrm{B}_{12}$ ) plays an important role in folate metabolism because of its action as cofactor for methionine synthase (MTR) enzyme. ${ }^{18}$ Thus, genetic variants in the TC2 gene possibly have an influence on cellular methylation reactions and on the risk that the mother may bear a DS child. The continuing studies on the etiology of DS are motivated by the importance of this subject for families, given the repercussions from the birth of a child with DS.

\section{口BJECTIVE}

This study had the objective of investigating the RFC1 A80G and TC2 C776G polymorphisms as maternal risk factors for DS.

\section{METHDDS}

This was an analytical cross-sectional study with a control group carried out at Faculdade de Medicina de São José do Rio Preto (Famerp). After informed consent had been obtained, peripheral blood samples were taken from 67 mothers of DS individuals with free trisomy 21 (case group) and 113 mothers of individuals without the syndrome (control group). Mothers of DS individuals with translocation or mosaicism were not included in the study. The average age among the mothers at the time of blood collection was $36.7 \pm 10.4$ years in the case group and $40.5 \pm 8.2$ years in the control group.

For molecular analysis, DNA was extracted from peripheral blood leukocytes, as described by Miller et al. ${ }^{19}$ The RFC1 A80G polymorphism was investigated by means of the polymerase chain reaction with restriction fragment length polymorphism (PCRRFLP), using the primer sequences described by Födinger et al. ${ }^{20}$ and the enzyme $C f o I$ to recognize the polymorphic site. The evaluation of the TC2 C776G polymorphism was
- Joice Matos Biselli

- Daniela Brumati

- Vivian Fernanda Frigeri

- Bruna Lancia Zampieri

- Eny Maria Goloni-Bertollo

שÉrika Cristina Pavarino-Bertelli

\section{ABSTRACT}

CONTEXT AND OBJECTIVE: There is evidence that polymorphisms of genes involved in folate metabolism may be associated with higher risk that mothers may bear a Down's syndrome (DS) child. This study therefore had the objective of investigating the A80G polymorphism of the reduced folate carrier 1 (RFCl) gene and the C776G polymorphism of the transcobalamin 2 (TC2) gene as maternal risk factors for DS among Brazilian women.

DESIGN AND SETTING: Analytical cross-sectional study with control group, at Faculdade de Medicina de São José do Rio Preto (Famerp).

METHODS: Sixty-seven mothers of DS individuals with free trisomy 21 , and 113 control mothers, were studied. Molecular analysis of the polymorphisms was performed by means of the polymerase chain reaction with restriction fragment length polymorphism (PCR-RFLP), followed by electrophoresis on $2 \%$ agarose gel.

RESULTS: The frequencies of the polymorphic alleles were 0.51 and 0.52 for RFC $180 G$, and 0.34 and 0.34 for TC2 776G, in the case and control groups, respectively. Thus, there were no differences between the groups in relation to either the allele or the genotype frequency, for both polymorphisms $(\mathrm{P}=0.696$ for $R F C$ ) $A 80 G ; P=0.166$ for TC2 C776G; $P=0.268$ for combined genotypes).

CONCLUSION: There was no evidence of any association between the RFC 1 A80G and TC2 C776G polymorphisms and the maternal risk of DS in the sample evaluated.

KEY WORDS: Down syndrome. Polymorphism, genetic. Folic acid. Nondisjunction, genetic. Transcobalamins. 
performed by means of PCR-RFLP using the forward primer 5'- CAT CAG AAC AGT GCG AGA GG -3' and the reverse primer 5'- GTG CCA GAC AGT CTG GGA AG -3 , and the enzyme $\operatorname{ScrF1}$ to recognize the polymorphic site. ${ }^{21}$ The resulting fragments from enzyme digestion were then subjected to electrophoresis on $2 \%$ agarose gel.

The chi-squared test was used for statistical analysis on genotype frequencies. Comparisons of maternal age between the groups was carried out by using Student's $t$ test; $P$ values $\leq 0.05$ were taken to be statistically significant.

RESULTS

Table 1 presents the distribution of the groups according to maternal age. The mean maternal age in the case group was $32 \pm 8.6$ years, and in the control group, it was $27.4 \pm$ 5.5 years $(\mathrm{P}<0.0001)$.

The frequencies of the polymorphic alleles RFC1 80G and TC2 776G were 0.51 and 0.34 in the case group and 0.52 and 0.34 in the control group, respectively. The genotype distribution of the polymorphisms is presented in Table 2. There were no significant differences in genotype distribution between the groups ( $\mathrm{P}=0.696$ for RFC1 A80G; $\mathrm{P}=0.166$ for TC2 C776G).

Analysis of the combined genotypes of the two polymorphisms did not show any statistically significant differences between the groups $(\mathrm{P}=0.268)$. Nor did the genotypes differentiate between the groups when only

Table 1. Distribution of the case $(n=67)$ and control $(n=113)$ groups according to maternal age

\begin{tabular}{lcc}
\hline Maternal age & Case $\mathbf{n}(\%)$ & Control $\mathbf{n}(\%)$ \\
\hline$\leq 20$ years & $6(9.0)$ & $15(13.3)$ \\
$>20-30$ years & $26(38.8)$ & $66(58.4)$ \\
$>30-35$ years & $7(10.4)$ & $23(20.3)$ \\
$>35$ years & $28(41.8)$ & $9(8.0)$ \\
\hline
\end{tabular}

Table 2. Genotype distribution of the RFC1 A80G and TC2 C776G polymorphisms between the case $(n=67)$ and control $(n=113)$ groups

\begin{tabular}{ccc}
\hline Genotypes & Case $\mathbf{n}(\%)$ & Control $\mathbf{n}(\%)$ \\
\hline RFC1 A80G & & \\
AA & $14(20.9)$ & $30(26.5)$ \\
AG & $33(49.3)$ & $49(43.4)$ \\
GG & $20(29.9)$ & $34(30.1)$ \\
TC2 C776G & & \\
CC & $32(47.8)$ & $48(42.5)$ \\
CG & $24(35.8)$ & $54(47.8)$ \\
GG & $11(16.4)$ & $11(9.7)$ \\
\hline
\end{tabular}

Occurrences of births of children with DS among young mothers suggests that advanced maternal age is not the only risk factor involved. Investigation of genetic polymorphisms that lead to abnormalities in folate metabolism products is the approach furthest investigated at the present time. ${ }^{28}$

James et al. ${ }^{29}$ reported that mothers with DS children have abnormal folate metabolism. They suggested that a variant of the methylenetetrahydrofolate reductase gene (MTHFR C677T), which regulates cellular methylation reactions, could lead to DNA hypomethylation and consequently to chromosomal segregation errors. Other genes involved in the folate metabolic pathway have been investigated as maternal risk factors for DS, such as $R F C 1, M T R$, methionine synthase reductase $(M T R R)$, cystathionine B-synthase $(C B S)$. Evidence indicating the contribution of variants of these genes towards the maternal risk of bearing a DS child has been put forward. ${ }^{9-12}$

However, the few studies that have evaluated the influence of RFC1 A80G polymorphism, including a previous study by our group, ${ }^{9}$ did not observe any association between this variant per se and the maternal risk of bearing a DS child, ${ }^{9,10,30}$ thereby corroborating the present study. Higher maternal risk of DS has been observed in the presence of this polymorphism, in combination with other genetic polymorphisms relating to folate metabolism, such as MTHFR C677T, MTHFR A1298C and MTRA2756G. ${ }^{9}{ }^{10}$ This may be due to the small impact of RFC1 A80G polymorphism on the affinity and transport efficiency of the variant enzyme in relation to the wild-type enzyme. ${ }^{31}$

With regard to TC2 C776G polymorphism, the present study is, to our knowledge, the first to investigate the contribution of polymorphisms of the cobalamin-transporting gene (an important cofactor for folate metabolism), in relation to the maternal risk of bearing a DS child. There is evidence for an association between this genetic variant and the maternal risk of bearing a child with neural tube defects, ${ }^{32}$ which are influenced by genetic determinants involved in folate metabolism.

Evidence showing a higher frequency of DS cases in families with a risk of neural tube defects, and vice versa, ${ }^{33}$ strengthens the notion that the same genetic determinants of folate metabolism influence both disorders. ${ }^{34}$ However, in the present study, no association was observed between the TC2 C776G polymorphism and the maternal risk of bearing a DS child. It is widely accepted that 
supplementation or fortification with folic acid reduces the risk of neural tube defects, ${ }^{35,36}$ and it is believed that supplementation with cobalamin in combination with folate could contribute towards reducing this risk. ${ }^{18,32}$
CDNCLUSION

No evidence for an association between RFC1 A80G and TC2 C776G polymorphisms and the maternal risk of bearing a DS child was observed in this study. Thus, further stud- ies including these and other polymorphisms involved in folate metabolism could provide a better understanding of the role of genetic variants in the etiology of the chromosomal nondisjunction that results in DS.
1. Oliver TR, Feingold E, Yu K, et al. New insights into human nondisjunction of chromosome 21 in oocytes. PLoS Genet. 2008;14;4(3):e1000033.

2. Jyothy A, Kumar KS, Mallikarjuna GN, et al. Parental age and the origin of extra chromosome 21 in Down syndrome. J Hum Genet. 2001;46(6):347-50.

3. Gusmão FA, Tavares EJ, Moreira LM. Idade materna e síndrome de Down no Nordeste do Brasil. [Maternal age and Down syndrome in Northeast Brazil]. Cad Saude Publica. 2003;19(4):973-8.

4. Beiguelman B, Krieger H, Silva LM. Maternal age and Down syndrome in Southeastern Brazil. Rev Bras Genet = Braz J Genet. 1996;19(4):637-40.

5. Fenech M. Micronutrients and genomic stability: a new paradigm for recommended dietary allowances (RDAs). Food Chem Toxicol. 2002;40(8):1113-7.

6. Finkelstein JD, Martin JJ. Homocysteine. Int J Biochem Cell Biol. 2000;32(4):385-9.

7. D'Alessio AC, Szyf M. Epigenetic tête-à-tête: the bilateral relationship between chromatin modifications and DNA methylation. Biochem Cell Biol. 2006;84(4):463-76.

8. Sciandrello G, Caradonna F, Mauro M, Barbata G. Arsenicinduced DNA hypomethylation affects chromosomal instability in mammalian cells. Carcinogenesis. 2004;25(3):413-7.

9. Biselli JM, Goloni-Bertollo EM, Zampieri BL, Haddad R, Eberlin MN, Pavarino-Bertelli EC. Genetic polymorphisms involved in folate metabolism and elevated plasma concentrations of homocysteine: maternal risk factors for Down syndrome in Brazil. Genet Mol Res. 2008;7(1):33-42.

10. Coppedè F, Marini G, Bargagna S, et al. Folate gene polymorphisms and the risk of Down syndrome pregnancies in young Italian women. Am J Med Genet A. 2006;140(10):1083-91.

11. da Silva LR, Vergani N, Galdieri L de C, et al. Relationship between polymorphisms in genes involved in homocysteine metabolism and maternal risk for Down syndrome in Brazil. Am J Med Genet A. 2005;135(3):263-7.

12. Acácio GL, Barini R, Bertuzzo CS, Couto EC, AnnichinoBizzacchi JM, Júnior WP. Methylenetetrahydrofolate reductase gene polymorphisms and their association with trisomy 21 . Prenat Diagn. 2005;25(13):1196-9.

13. Fillon-Emery N, Chango A, Mircher C, et al. Homocysteine concentrations in adults with trisomy 21 : effect of $\mathrm{B}$ vitamins and genetic polymorphisms. Am J Clin Nutr. 2004;80(6):1551-7.

14. Chango A, Emery-Fillon N, de Courey GP, et al. A polymorphism (80G- $>A$ ) in the reduced folate carrier gene and its as- sociations with folate status and homocysteinemia. Mol Genet Metab. 2000;70(4):310-5.

15. Nguyen TT, Dyer DL, Dunning DD, Rubin SA, Grant KE, Said HM. Human intestinal folate transport: cloning, expression, and distribution of complementary RNA. Gastroenterology. 1997;112(3):783-91.

16. Miller JW, Ramos MI, Garrod MG, Flynn MA, Green R Transcobalamin II $775 \mathrm{G}>\mathrm{C}$ polymorphism and indices of vitamin B12 status in healthy older adults. Blood. 2002;100(2):71820.

17. Afman LA, Lievers KJ, van der Put NM, Trijbels FJ, Blom H] Single nucleotide polymorphisms in the transcobalamin gene: relationship with transcobalamin concentrations and risk for neural tube defects. Eur J Hum Genet. 2002;10(7):433-8.

18. Yamada K, Gravel RA, Toraya T, Matthews RG. Human methionine synthase reductase is a molecular chaperone for human methionine synthase. Proc Natl Acad Sci U S A. 2006;103(25):9476-81.

19. Miller SA, Dykes DD, Polesky HF. A simple salting out procedure for extracting DNA from human nucleated cells. Nucleic Acids Res. 1988;16(3):1215.

20. Födinger M, Dierkes J, Skoupy S, et al. Effect of glutamate carboxypeptidase II and reduced folate carrier polymorphisms on folate and total homocysteine concentrations in dialysis patients. J Am Soc Nephrol. 2003;14(5):1314-9.

21. Pietrzyk JJ, Bik-Multanowski M. 776C $>$ G polymorphism of the transcobalamin II gene as a risk factor for spina bifida. Mol Genet Metab. 2003;80(3):364

22. Coelho IS. Doenças cromossômicas. Available from: http://www. ufv.br/dbg/BIO240/DC14.htm. Accessed in 2008 (Sep 10).

23. Barros ACSD, Zugaib M, Pereira PP, Guglielmi GF, Durante AA. Gestantes de pelo menos 45 anos de idade: consideraçôes sobre 40 casos. [Pregnant women of 45 or more. Considerations on 40 cases]. J Bras Ginecol. 1984;94(1/2):33-6.

24. Hansen JP. Older maternal age and pregnancy outcome: a review of the literature. Obstet Gynecol Surv. 1986;41(11):726-42.

25. Kiely JL, Paneth N, Susser M. An assessment of the effects of maternal age and parity in different components of perinatal mortality. Am J Epidemiol. 1986;123(3):444-54

26. Schupp T. Espaço médico: idade materna avançada. Available from: http://drauziovarella.ig.com.br/espaco/espaco. asp?doe_id=25. Accessed in 2008 (Sep 10).

27. Castilla EE, Lopez-Camelo JS, Paz JE. Atlas geográfico de las malformaciones congénitas en sudamérica. Rio de Janeiro: Fiocruz; 1995.
REFERENCES

28. Eskes TK. Abnormal folate metabolism in mothers with Down syndrome offspring: review of the literature. Eur J Obstet Gynecol Reprod Biol. 2006;124(2):130-3.

29. James SJ, Pogribna M, Pogribny IP, et al. Abnormal folate metabolism and mutation in the methylenetetrahydrofolate reductase gene may be maternal risk factors for Down syndrome. Am J Clin Nutr. 1999;70(4):495-501.

30. Chango A, Fillon-Emery N, Mircher C, et al. No association between common polymorphisms in genes of folate and homocysteine metabolism and the risk of Down's syndrome among French mothers. Br J Nutr. 2005;94(2):166-9.

31. Whetstine JR, Gifford AJ, Witt T, et al. Single nucleotide polymorphisms in the human reduced folate carrier: characterization of a high-frequency G/A variant at position 80 and transport properties of the His(27) and $\operatorname{Arg}(27)$ carriers. Clin Cancer Res. 2001;7(11):3416-22.

32. Guéant-Rodriguez RM, Rendeli C, Namour B, et al. Transcobalamin and methionine synthase reductase mutated polymorphisms aggravate the risk of neural tube defects in humans. Neurosci Lett. 2003;344(3):189-92.

33. Barkai G, Arbuzova S, Berkenstadt M, Heifetz S, Cuckle H. Frequency of Down's syndrome and neural-tube defects in the same family. Lancet. 2003;361(9366):1331-5.

34. Guéant JL, Guéant-Rodriguez RM, Anello G, et al. Genetic determinants of folate and vitamin B12 metabolism: a common pathway in neural tube defect and Down syndrome? Clin Chem Lab Med. 2003;41(11):1473-7.

35. De Wals P, Tairou F, Van Allen MI, et al. Reduction in neuraltube defects after folic acid fortification in Canada. N Engl J Med. 2007;357(2):135-42

36. Pitkin RM. Folate and neural tube defects. Am J Clin Nutr. 2007;85(1):285S-288S

Acknowledgements: The authors thank Prof. Dr. José Antônio Cordeiro for his assistance in the statistical analysis and Prof. Adília Maria Pires Sciarra for her assistance in translating this article

Sources of funding: Fundação de Amparo à Pesquisa do Estado de São Paulo (Fapesp) - 04/15944-5; Coordenação de Aperfeiçoamento de Pessoal de Nível Superior (Capes) - CGPP 046/2006); Conselho Nacional de Desenvolvimento Científico e Tecnológico (CNPq) - 3210/2006 and $3211 / 2006$

Conflict of interest: Not declared

Date of first submission: December 9, 2007

Last received: June 23, 2008

Accepted: November 4, 2008 


\section{AUTHOR INFDRMATIDN}

Joice Matos Biselli, MSc. Genetics and Molecular Biology Research Unit, Department of Molecular Biology, Faculdade de Medicina de São José do Rio Preto (Famerp), São José do Rio Preto, São Paulo, Brazil.

Daniela Brumati, BSc. Nurse, Faculdade de Medicina de São José do Rio Preto (Famerp), São José do Rio Preto, São Paulo, Brazil.

Vivian Fernanda Frigeri, BSc. Nurse, Faculdade de Medicina de São José do Rio Preto (Famerp), São José do Rio Preto, São Paulo, Brazil.

Bruna Lancia Zampieri, MSc. Student. Genetics and Molecular Biology Research Unity, Faculdade de Medicina de São José do Rio Preto (Famerp), São José do Rio Preto, São Paulo, Brazil.

Eny Maria Goloni-Bertollo, PhD. Genetics and Molecular Biology Research Unit, Department of Molecular Biology, Faculdade de Medicina de São José do Rio Preto (Famerp), São José do Rio Preto, São Paulo, Brazil.

Érika Cristina Pavarino-Bertelli, PhD. Genetics and Molecular Biology Research Unit, Department of Molecular Biology, Faculdade de Medicina de São José do Rio Preto (Famerp), São José do Rio Preto, São Paulo, Brazil.

Address for correspondence

Érika Cristina Pavarino Bertelli

Faculdade de Medicina de São José do Rio Preto

(Famerp)

Unidade de Pesquisa em Genética e Biologia Molecular (UPGEM)

Av. Brigadeiro Faria Lima, 5.416 - Bloco U-6

São José do Rio Preto (SP) - Brasil

CEP 15090-000

Tel. (+55 17) $3201-5720$

Fax. (+55 17) 3201-5708

E-mail: erika@famerp.br

Copyright (C) 2008, Associação Paulista de Medicina
Polimorfismos do gene carregador de folato reduzido (RFC1) A80G e transcobalamina 2 (TC2) C776G na etiologia da síndrome de Down

CONTEXTO E OBJETIVO: Considerando as evidências de que polimorfismos em genes envolvidos no metabolismo do folato podem estar associados ao risco materno elevado para a síndrome de Down (SD), o objetivo deste estudo foi investigar os polimorfismos A80G do gene carregador de folato reduzido 1 (RFC1) e C776G do gene transcobalamina 2 (TC2) como fatores de risco maternos para a SD em mulheres brasileiras.

TIPO E ESTUDO LOCAL: Estudo transversal analítico com grupo controle, realizado na Faculdade de Medicina de São José do Rio Preto (Famerp).

MÉTODOS: Foram avaliadas 67 mães de indivíduos com trissomia livre do 21 e 113 mães de indivíduos sem a síndrome. A análise molecular dos polimorfismos foi realizada pela técnica de reação em cadeia da polimerase/polimorfismo de comprimento fragmentos de restrição (PCR-RFLP), seguida por eletroforese em gel de agarose $2 \%$

RESULTADOS: As freqüências dos alelos polimórficos foram de 0,51 e 0,52 para RFC1 80G e 0,34 e 0,34 para TC2 $776 \mathrm{G}$ nos grupos caso e controle, respectivamente. Assim, não houve diferença nas freqüências alélicas e genotípicas para ambos os polimorfismos entre os grupos $(\mathrm{P}=0,696$ para RFC1 A80G; $\mathrm{P}=$ 0,166 para TC2 C776G; $p=0,268$ para genótipos combinados).

CONCLUSÃO: Não há evidência de associação entre os polimorfismos RFC1 A80G e TC2 C776G e o risco materno para a SD na casuística avaliada.

PALAVRAS-CHAVE: Síndrome de Down. Polimorfismo genético. Ácido fólico. Não-disjunção genética. Transcobalaminas. 